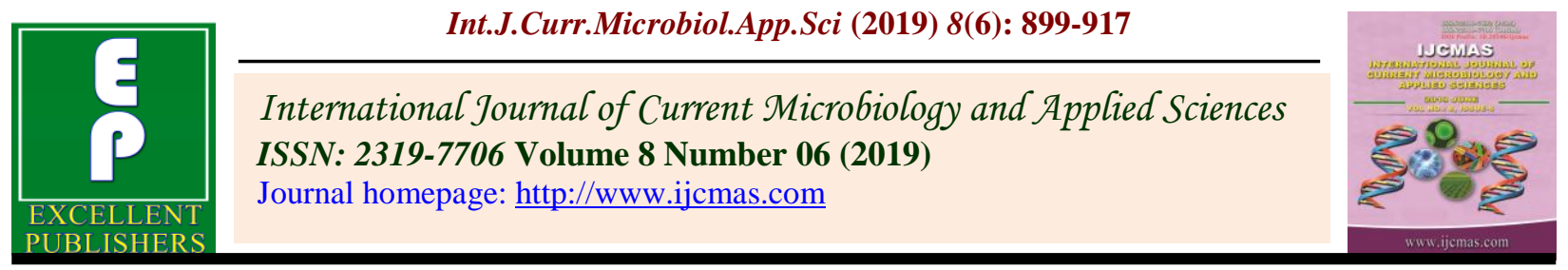

Original Research Article

https://doi.org/10.20546/ijcmas.2019.806.109

\title{
Impact of Integrated Nutrient Management on Nutrient Content, Nutrient Uptake, Protein Content and Grain Yield in Maize (Zea mays L.)-Wheat (Triticum aestivum L.) Cropping System in an Acid Alfisol
}

\author{
Karan Verma* and A.D. Bindra \\ Department of Agronomy, Forages and Grassland Management, COA, CSK Himachal \\ Pradesh Krishi Vishvavidyalaya, Palampur, Himachal Pradesh- 176062 India \\ *Corresponding author
}

\begin{abstract}
Keywords
Integrated nutrient management,

Nutrient content,

Nutrient uptake,

Protein content,

Grain yield, Maize and Wheat

Article Info

Accepted:

10 May 2019

Available Online:

10 June 2019 (2016-17) at the experimental farm of Department of Agronomy, Forages and Grassland Management, Himachal Pradesh Krishi Vishvavidyalaya, Palampur. Experiment was laid out in randomized block design with three replications comprising seven treatments as applied to maize as main plot i.e. 50\% nitrogen through FYM $+50 \%$ nitrogen through inorganic fertilizer $\left(\mathrm{T}_{1}\right) ; 50 \%$ nitrogen through fortified vermicompost $+50 \%$ nitrogen through inorganic fertilizer $\left(\mathrm{T}_{2}\right) ; 50 \%$ nitrogen through vermicompost $+50 \%$ nitrogen through inorganic fertilizer $\left(\mathrm{T}_{3}\right) ; 25 \%$ nitrogen through $\mathrm{FYM}+75 \%$ nitrogen through inorganic fertilizer $\left(\mathrm{T}_{4}\right) ; 25 \%$ nitrogen through fortified vermicompost $+75 \%$ nitrogen through inorganic fertilizer $\left(\mathrm{T}_{5}\right) ; 25 \%$ nitrogen through vermicompost $+75 \%$ nitrogen through inorganic fertilizer $\left(\mathrm{T}_{6}\right)$ and recommended dose of NPK through inorganic fertilizer $\left(\mathrm{T}_{7}\right)$; and three treatments to wheat i.e. 50\% (recommended dose of NPK through inorganic fertilizers $\left(\mathrm{F}_{1}\right) ; 75 \%$ RDF $\left(\mathrm{F}_{2}\right)$ and $100 \%$ RDF $\left(\mathrm{F}_{3}\right)$ as sub plots. Higher NPK uptake both in maize and wheat were recorded with combined application of organics and inorganics. Higher content and uptake of nitrogen was observed with $25 \% \mathrm{~N}$ through fortified vermicompost $+75 \% \mathrm{~N}$ through inorganic fertilizer $\left(\mathrm{T}_{5}\right)$. However phosphorus and potassium content and uptake was higher in $T_{7}$ treatment but being at par with $T_{5}$. Residual effect on wheat content and uptake was non significant.
\end{abstract}

\section{A B S T R A C T}

A field experiment was conducted for two consecutive years from kharif (2015) to rabi

\section{Introduction}

Maize (Zea mays L.) has become very popular cereal crop in India because of the increasing market price and high production potential of hybrid varieties in both irrigated as well as rainfed conditions. Moreover, in irrigated areas farmers fetch the income equal to the cash crops in comparatively short time period of 120-130 days by cultivating hybrid maize varieties.

The productivity of maize is largely dependent on its nutrient management. It is well known fact that maize is a heavy feeder of nutrients and because of its $\mathrm{C}_{4}$, nature it is very efficient in converting solar energy into production of dry matter. Globally, maize is 
known as Miracle crop and "Queen of Cereals" due to high genetic yield potentials than any other cereals counterpart (Kannan et al., 2013). India is the second-most important maize growing country in Asia and world's sixth largest producer and the fifth largest consumer. In India, maize is cultivated in an area of 8.69 million hectares having production of 21.81 million tonnes with a productivity of $2509 \mathrm{~kg} \mathrm{ha}^{-1}$ (Anonymous 2017). Maize is the major crop of the Himachal Pradesh. The production of maize, which was cultivated on an area 0.30 million hectares having production 0.67 million tonnes with a productivity of $2270 \mathrm{~kg} \mathrm{ha}^{-1}$ (Anonymous 2017).

Wheat (Triticum aestivum L.) is the most important food-grain of India and is the staple food of millions of Indians, particularly in the northern and north-western parts of the country. It is world's second important cereal crop after rice. India is second largest producer of wheat in the world after China with about 12 per cent share in total world wheat production. Wheat is an important post monsoon crop of the country as India is ranking second in wheat production with an area of 30.2 million hectare having production of 93.5 million tonnes along with productivity of $3093 \mathrm{~kg} \mathrm{ha}^{-1}$ (Anonymous 2017).

In Himachal Pradesh, also wheat among other cereals occupies the largest area of about 0.35 million hectare with total production of 0.68 million tonnes along with a productivity of $1968 \mathrm{~kg} \mathrm{ha}^{-1}$ (Anonymous 2017). Maize (Zea mays L.)-wheat (Triticum aestivum L.) both belonging to family Poaceae, is the most dominant cropping system in the State of Himachal Pradesh, contributing about 85 per cent of the total food grain production in the state. However, the productivity of this existing cropping system in small and marginal farmer's field is very low (Chaudhary and Singh 1992) besides having lower cropping intensity as the fields remain idle for nearly three months.

The chemical fertilizers alone cannot meet the requirement of crops and cropping systems, because of their high cost and less residual effects of chemicals, hence there is increasing trend towards use of organic manures. Incorporation of organic matter either in the form of crop residues or farmyard manure/ vermicompost/compost are vital for supplementing plant nutrients and maintenance of soil fertility, as it is an important soil component which influences the physical, chemical and biological properties of soil.

Incorporation of organic manures influence soil enzymatic activity either because of the composition of the added materials or they increase microbial activity of the soil (DeForest et al., 2012). Farmyard manure application to the crop is an age old practice. Well decomposed FYM in addition to supplying of plant nutrients, acts as binding material and improves the soil physical properties. Beneficial effects of earth worms and their cast were known as early as in Darwin's era.

\section{Objectives}

1. To study the effect of organic and inorganic sources of nutrients on growth, development and yield of maize,

2. To study the residual effect of organic and inorganic sources on growth, development and yield of wheat,

3. To study the effect of organic and inorganic sources on physical, chemical and biological properties of soil and

4. To study the economics of different treatments 


\section{Materials and Methods}

\section{Location}

The experimental farm is situated at $32^{0} 6 \mathrm{~N}$ latitude and 7603' $\mathrm{E}$ longitude and at an elevation of $1290 \mathrm{~m}$ above mean sea level in North Western Himalaya. The area represents the mid-hill zone of Himachal Pradesh. The region is endowed with mild summers and cool winters. The mean weekly meteorological observations recorded at the meteorological observatory of the Department of Agronomy, Forages and Grassland Management, College of Agriculture, CSK HPKV, Palampur during the crop growth period. The meteorological data revealed that maximum mean monthly temperature ranged from $14.3^{\circ} \mathrm{C}$ to $32.7^{\circ} \mathrm{C}$ and minimum from $2.4^{\circ} \mathrm{C}$ to $19.7^{\circ} \mathrm{C}$ during the first year, and $11.6^{\circ} \mathrm{C}$ to $32.9^{\circ} \mathrm{C}$ and $2.8^{\circ} \mathrm{C}$ to $19.6^{\circ} \mathrm{C}$ in second year of experimentation. The relative humidity ranged between 27.4 per cent and 94.1 per cent during 2015-16 and between 42.3 per cent to 95.5 per cent during 2016-17, with highest humidity recorded during the month of August. This month also received highest amount of rainfall during both the years which was $416 \mathrm{~mm}$ in 2015 and 315 $\mathrm{mm}$ in 2016. The maximum bright sunshine hours were recorded during 2nd week of May (77.03 hours) in 2015 and last week of April (84.05 hours) in 2016.

\section{Experimental design}

Seven integrated nutrient management treatments in maize viz., $50 \% \mathrm{~N}$ through FYM $+50 \% \mathrm{~N}$ through inorganic fertilizer; $50 \% \mathrm{~N}$ through fortified vermicompost $+50 \% \mathrm{~N}$ through inorganic fertilizer; $50 \% \mathrm{~N}$ through vermicompost $+50 \% \mathrm{~N}$ through inorganic fertilizer; $25 \% \mathrm{~N}$ through FYM $+75 \% \mathrm{~N}$ through inorganic fertilizer; $25 \% \mathrm{~N}$ through fortified vermicompost $+75 \% \mathrm{~N}$ through inorganic fertilizer; $25 \% \mathrm{~N}$ through vermicompost $+75 \% \mathrm{~N}$ through inorganic fertilizer and recommended dose of NPK through inorganic fertilizers and three treatments in wheat viz., 50\% RDF (recommended dose of NPK through inorganic fertilizers); $75 \% \mathrm{RDF}$ and $100 \%$ RDF constituting 21 treatment combinations, were evaluated for two consecutive years commencing from kharif, 2015 to rabi, 201617 at Palampur in maize-wheat cropping sequence. In the first kharif season seven fertility treatments in maize were evaluated in randomized block design with three replications. Subsequently from rabi, 201516 , the treatments in maize were assigned to main plots and those in wheat to sub plots in a split plot design.

\section{Agronomic details}

Maize variety K 25 Gold (Kanchan Ganga) with spacing $60 \times 20 \mathrm{~cm}$. Wheat variety HPW-236 is recommended for mid hills area for timely sowing in irrigated areas with spacing 22.5 X $5 \mathrm{~cm}$. Before sowing of maize, FYM as per treatment was applied at the time of final field preparation. Vermicompost and fortified vermicompost were applied at seeding below the seeding furrows in their respective treatments. The $\mathrm{N}, \mathrm{P}$ and $\mathrm{K}$ fertilizers were applied as per treatment through urea, SSP and MOP @ 120, 60 and $40 \mathrm{~kg} \mathrm{ha}^{-1}$, recommend dose of fertilizer respectively. One third $\mathrm{N}$ and whole $\mathrm{P}_{2} \mathrm{O}_{5}$ and $\mathrm{K}_{2} \mathrm{O}$ were applied at the time of sowing. The remaining two third of $\mathrm{N}$ was applied in two equal splits, one at knee-high and the other at tasseling stage. In wheat crop, N, P and K were applied @120,60 and 30 kg ha ${ }^{-1}$ recommend dose of fertilizer through urea IFFCO 12:32:16 and urea respectively. Half $\mathrm{N}$ and whole $\mathrm{P}_{2} \mathrm{O}_{5}$ and $\mathrm{K}_{2} \mathrm{O}$ were applied at the time of sowing. The remaining nitrogen was top dressed after one month of sowing. Nitrogen as per treatment was given by organics and phosphorus and potassium supplied by these organics were adjusted accordingly as per treatment (Table 1). 


\section{Details of observations recorded}

\section{NPK content and uptake in maize and wheat grain and straw}

Composite samples of seed and straw taken from each plot at harvest stage of maize and wheat crop were processed and analyzed for total N, P and $\mathrm{K}$ content employing standard methods (Jackson, 1973 and Black, 1965).

The N, P, K uptake in maize and wheat after harvest was determined by applying the following formula:

Nutrient (N/P/K) concentration (\%)

Nutrient uptake $=$

Seed/straw yield $\left(\mathrm{kg} \mathrm{ha}^{-1}\right)(\mathrm{N} / \mathrm{P} / \mathrm{K})\left(\mathrm{kg} \mathrm{ha}^{-1}\right)$

\section{Protein content $(\%)$ in maize and wheat grains}

Protein content of maize and wheat grains from different treatments was estimated by determining nitrogen content by Microkjeldahl procedure (Piper 1966). Total N values thus obtained were multiplied with a factor of 6.25 to obtain the protein content.

\section{Grain yield $\left(\mathrm{kg} \mathrm{ha}^{-1}\right)$}

The produce from each net plot was harvested and threshed after sun drying. The grains were cleaned and weighed after threshing. The weight of grains recorded on each plot was converted into $\left(\mathrm{kg} \mathrm{ha}^{-1}\right)$ by multiplying with a factor 1453.48.

\section{Straw yield (kg ha $\left.{ }^{-1}\right)$}

Total biological yield (grain + straw) from each net plot was recorded by weighing the sun dried harvested produce. The straw yield was worked out by subtracting the grain yield from biological yield $\left(\mathrm{kg} \mathrm{ha}^{-1}\right)$.

\section{Nutrient content}

Data on content of nitrogen, phosphorus and potassium in maize grain and stover have been given in Table 2 . The data revealed nonsignificant differences in the contents of NPK both in grain and stover of maize due to fertility treatments both in maize and wheat. It may be obvious as all treatments in maize are supplied/supplemented $100 \%$ NPK through organics or inorganics. The fertilizer supply variation in treatments in wheat also did not cause variation in the content of nutrients in maize grain and stover probably due to exhaustive nature of both the crops. The interaction between nutrient management treatments in maize and wheat also had no significant effect on content of NPK in maize grain and stover.

\section{Nutrient uptake}

Data on the uptake of nitrogen, phosphorus and potassium in maize grain, stover and total have been given in Tables 3.1, 3.2 and 3.3, respectively. Nutrient uptake is a function of content and dry matter. In the present study contents did not vary significantly due to fertility treatments in maize and wheat, whatever, variation was therefore, observed, was owed to dry matter production only.

\section{Nitrogen uptake in grain, stover and total}

The data in Table 3.1 revealed that variation in $\mathrm{N}$ uptake was significantly in grain and stover and thus total uptake by maize crop due to different treatments in maize. Higher uptake of nitrogen in grain, stover and total 
uptake was recorded in treatment $25 \% \mathrm{~N}$ through fortified vermicompost $+75 \% \mathrm{~N}$ through fertilizer $\left(\mathrm{T}_{5}\right)$ which was found at par with recommended dose of fertilizer $\left(\mathrm{T}_{7}\right)$ and $25 \% \mathrm{~N}$ through vermicompost $+75 \% \mathrm{~N}$ though fertilizer $\left(\mathrm{T}_{6}\right)$ during 2015. However, during $201650 \% \mathrm{~N}$ through fortified vermicompost $+50 \% \mathrm{~N}$ through fertilizer $\left(\mathrm{T}_{2}\right)$ and $25 \% \mathrm{~N}$ through farm yard manure $+75 \%$ $\mathrm{N}$ through fertilizer $\left(\mathrm{T}_{4}\right)$ also remained at par with former treatments. Since these treatments increased all the growth characters and subsequently resulted in more dry matter yield, more $\mathrm{N}$ uptake in grain and stover was obvious compared to rest of the treatments. Although organic manures contain plant nutrients in small quantities as compared to the fertilizer, the presence of growth promoting substances like enzyme and hormones besides supplying plant nutrients make them essential for improvement of soil fertility and productivity. The maintenance of soil physico-chemical and biological properties due to organic and inorganics has been amply supported by Kannan et al., (2013); Choudhary and Kumar (2013) and Sheoran et al., (2015).

The residual effect of fertilizers applied in wheat was not significant on $\mathrm{N}$ uptake in grain and stover and thus on total uptake by maize crop. The interaction effect between nutrient management treatments in maize and wheat on nitrogen uptake by maize grain, stover and total was also not significant.

Phosphorus uptake in grain, stover and total $\left(\mathrm{kg} \mathrm{ha}^{-1}\right)$

Data pertaining to phosphorus uptake in maize grain and stover and total given in Table 3.2 revealed that significantly higher uptake of phosphorus in grain, stover and total of maize was recorded in recommended dose of fertilizer $\left(T_{7}\right)$. However, treatments $T_{2}$ to $\mathrm{T}_{6}$ also remained at par with this treatment except $\mathrm{T}_{3}$ in case of total uptake during both the years of study. The balanced nutrients supply from integrated nutrient sources increased their availability and hence, resulted in more nutrient uptake by the crops. Samaneh et al., (2013) also reported that NPK uptake increased significantly in maize crop by integration of organic and inorganic sources of $\mathrm{N}$.

The residual effect of fertilizers applied in wheat was not significant on $\mathrm{P}$ uptake in grain, stover and thus total uptake by maize crop. The interaction effect between nutrient management treatments in maize and wheat on phosphorus uptake by maize grain, stover and total was also not significant.

\section{Potassium uptake in grain, stover and total $\left(\mathrm{kg} \mathrm{ha}^{-1}\right)$}

Data on potassium uptake in grains, stover and total uptake given in Table 3.3 showed similar trend of uptake as that for nitrogen and phosphorus uptake.

Significantly higher uptake of potassium in grain, stover and total of maize was recorded in recommended dose of fertilizer $\left(\mathrm{T}_{7}\right)$ during both the years. However, this treatment remained at par with $25 \% \mathrm{~N}$ through fortified vermicompost $+75 \% \mathrm{~N}$ through fertilizer $\left(\mathrm{T}_{5}\right)$ and $25 \% \mathrm{~N}$ through vermicompost $+75 \% \mathrm{~N}$ through fertilizer $\left(\mathrm{T}_{6}\right)$ during both the years. Uptake was statistically lower in the treatments getting lower doses of organics and chemical fertilizers in both years of observations.

Higher dry matter production resulted in increased uptake of potassium in grains as well as stover. Similar were the observations of Kumar and Dhar (2010) and Manjhi et al., (2014). $\mathrm{T}_{1}(50 \% \mathrm{~N}$ substitution through FYM) had lower numerical values of potassium uptake in grain and stover thus total.

The residual effect of fertilizers applied in wheat was not significant on $\mathrm{K}$ uptake in 
grain, stover and total uptake by maize crop. The interaction effects among nutrient management treatments in maize and wheat on potassium uptake was also not significant.

\section{Protein content}

Nutrient management treatments in maize and wheat could not significantly influence protein content in grains of maize during both the years (Table 4). The interaction was also not significant on protein content.

\section{Nutrient content}

Data on the content of nitrogen, phosphorus and potassium in grain and straw of wheat have been presented in Table 5 .

A perusal of the data revealed that there were no significant differences in the content of NPK both in grain and straw of wheat due to fertility treatments applied both in maize and wheat during both the years.

The fertilizer supply variation of treatments in wheat also did not show significant difference in the contents of nutrients in wheat grain and straw probably due to exhaustive nature of both the crops.

The inverse nitrogen yield relationship may be operative but higher supply of $\mathrm{N}$ lead to higher yield and thus not significantly affecting the content. The interaction between nutrient application treatments in maize and wheat also had no effect on content of NPK in wheat grain and straw during both the years.

\section{Nutrient uptake}

Data on the uptake of nitrogen, phosphorus and potassium in wheat grain, straw and total have been given in Tables 6.1, 6.2 and 6.3, respectively.

\section{Nitrogen uptake in grain, straw and total}

The data in Table 6.1 indicated that organic and inorganic treatments in maize did not significantly influence $\mathrm{N}$ uptake in grain and straw and thus total uptake by wheat crop.

Fertility treatments applied in wheat significantly influenced $\mathrm{N}$ uptake in grain and straw and thus total by wheat crop. Application of $100 \%$ recommended dose of fertilizer $\left(\mathrm{F}_{3}\right)$ resulted in significantly higher nitrogen uptake in grain, straw and total followed by $75 \%$ and $50 \%$ recommended dose of fertilizer during both the years of experimentation. Nutrient uptake is a function of content and dry matter. These results are in conformity with the results obtained by Dwivedi et al., (2014). The interaction effect between nutrient management treatments in maize and wheat on nitrogen uptake by grain, straw and total was also not significant.

\section{Phosphorus uptake in grain, straw and} total $\left(\mathrm{kg} \mathrm{ha}^{-1}\right)$

The data on phosphorus uptake by wheat grain and straw and total have been given in Table 6.2. Data revealed non-significant differences among treatments on $\mathrm{P}$ uptake in grain and straw and total uptake by wheat crop during both the years.

Fertility treatments applied in wheat had significantly influenced $\mathrm{P}$ uptake in grain, straw and thus total uptake by wheat crop. Treatment receiving 100\% recommended dose of fertilizers $\left(\mathrm{F}_{3}\right)$ resulted in significantly highest $\mathrm{P}$ uptake in wheat grain, straw and total compared to $75 \%$ and $50 \%$ recommended dose of fertilizers.

Significantly lowest $\mathrm{P}$ uptake was recorded under $50 \%$ recommended doses of fertilizers during both the years. In case of uptake in straw $75 \%$ and $100 \%$ NPK were at par with 
each other. Similar results were also reported by Mahala et al., (2006); Shah et al., (2013); and Dwivedi et al., (2014). The interaction effect between nutrient management treatments in maize and wheat was not significant on phosphorus uptake by wheat grain, straw and total during both the years.

\section{Potassium uptake in grain, straw and total $\left(\mathrm{kg} \mathrm{ha}^{-1}\right)$}

Data on potassium uptake in grains, straw and total given in Table 6.3 revealed that fertility treatments in maize did not significantly influence potassium uptake in grain, straw and total during both the years of experimentation.

However, treatments applied in wheat had significantly influenced $\mathrm{K}$ uptake in grain, straw and thus total by wheat crop. Application of $100 \%$ recommended dose of fertilizers $\left(\mathrm{F}_{3}\right)$ gave significantly highest potassium uptake in grains, straw and total as compared to $75 \%$ and $50 \%$ recommended dose of fertilizers. Significantly lowest potassium uptake in wheat grains, straw and total was recorded under $50 \%$ recommended dose of fertilizers applied to wheat during both the years. The results of present study confirm the earlier findings of Shah and Wani (2017). The interaction effect between nutrient management treatments in maize and wheat on potassium uptake by wheat grain, straw and total was also not significant.

\section{Protein content (\%)}

Data on protein content have been given in Table 7. The data revealed that nutrient management treatments in maize and wheat could not influence statistically protein content in grains of wheat during both the year. The interaction between nutrient management treatments in maize and wheat was also not significant on protein content in wheat grains during both the years of investigation.

\section{Grain yield and stover yield}

The data on grain and stover yield of maize have been given in Table 8. The combined biological yield (grain and stover) of maize has been depicted in Figure 1.

\section{Grain yield ( $\left.\mathrm{kg} \mathrm{ha}^{-1}\right)$}

An examination of data presented in Table 8. Revealed that application of $25 \% \mathrm{~N}$ through fortified vermicompost $+75 \% \mathrm{~N}$ through fertilizer $\left(T_{5}\right)$ resulted in significantly higher grain yield of maize during 2015. However, it remained at par with recommended dose of fertilizer $\left(\mathrm{T}_{7}\right), 25 \% \mathrm{~N}$ through vermicompost $+75 \% \mathrm{~N}$ through fertilizer $\left(\mathrm{T}_{6}\right), 25 \% \mathrm{~N}$ through farm yard manure $+75 \% \mathrm{~N}$ through fertilizer $\left(\mathrm{T}_{4}\right), 50 \% \mathrm{~N}$ through fortified vermicompost $+50 \% \mathrm{~N}$ through fertilizer $\left(\mathrm{T}_{2}\right)$ and $50 \% \mathrm{~N}$ through vermicompost $+50 \% \mathrm{~N}$ through fertilizer $\left(\mathrm{T}_{3}\right)$. Increase in grain yield due to fortified vermicompost $\left(\mathrm{T}_{5}\right)$ over $50 \%$ $\mathrm{N}$ through farm yard manure $+50 \% \mathrm{~N}$ through fertilizer $\left(\mathrm{T}_{1}\right)$ was $18.72 \%$ during 2015. Almost similar trend was observed during second year of study except $50 \% \mathrm{~N}$ through farm yard manure $+50 \% \mathrm{~N}$ through fertilizer $\left(\mathrm{T}_{1}\right)$ remained inferior to $50 \% \mathrm{~N}$ through fortified vermicompost $+50 \% \mathrm{~N}$ through fertilizer $\left(\mathrm{T}_{2}\right)$ and $50 \% \mathrm{~N}$ through vermicompost $+50 \% \mathrm{~N}$ through fertilizer $\left(\mathrm{T}_{3}\right)$ respectively. Hence, fortified vermicompost $\left(\mathrm{T}_{5}\right)$ registered an increase in grain yield over farm yard manure $\left(\mathrm{T}_{1}\right)$ to the tune of $12.78 \%$. The increase in yield under these treatments was because of favorable influence of nutrient application on the growth and yield attributes of maize. The improvement in grain yield under treatments involving organic/vermicompost might be due to the improvement in soil physico-chemical properties (viz., $\mathrm{pH}$, bulk density, infiltration rate and microbial biomass carbon) and optimum availability of nutrients and organic carbon which acted as the growth and yield enhancing characters of maize crop. Further 
the grain yield of maize mainly depends upon the final plant population and yield of individual plant, the latter in turn depends upon the number of ears per plant and the weight of grains per cob which resulted in higher grain yield in maize. Similar results were also reported by More et al., (2013); Saini and Kumar (2014) and Nasab et al., (2015).

Residual effects of inorganic fertilizer levels applied in wheat were not significant on the grain yield of maize. The interaction between nutrient management treatments in maize and wheat was not significant for grain yield of maize.

\section{Stover yield ( $\left.\mathrm{kg} \mathrm{ha}^{-1}\right)$}

The perusal of data in Table 8 showed that different fertility treatments in maize also significantly influenced the stover yield of maize. Almost similar trend in stover yield was observed as it was noticed in grain yield of maize. Application of vermicompost and FYM at different levels $T_{2}$ to $T_{6}$ remained at par with recommended dose of fertilizer $\left(\mathrm{T}_{7}\right)$ during 2015. Further, 25\% N through fortified vermicompost $+75 \% \mathrm{~N}$ through fertilizer $\left(\mathrm{T}_{5}\right)$ and recommend dose of fertilizers $\left(\mathrm{T}_{7}\right)$ were found superior to $50 \% \mathrm{~N}$ through farm yard manure $+50 \% \mathrm{~N}$ through fertilizer $\left(\mathrm{T}_{1}\right)$.

During second year also $\left(\mathrm{T}_{5}\right),\left(\mathrm{T}_{6}\right)$ and $\left(\mathrm{T}_{7}\right)$ remaining at pat with each other were found superior to all other treatments.

These results are in close conformity with the finding of Channabasanagowda et al., (2008) and Saini and Kumar (2014) who have shown that the slight different action of vermicompost or FYM substitution may be because of slow release of nutrient from them due to slow mineralization. Fertilizers applied in wheat did not have any significantly influence on stover yield of maize. Also the interaction effects were not significant on stover yield of maize.

\section{Biological yield ( $\left.\mathrm{kg} \mathrm{ha}^{-1}\right)$}

Biological yield depicted in Figure $2 \mathrm{a}$ and $\mathrm{b}$ followed the trend of grain and stover during both years of experimentation. Application of $25 \% \mathrm{~N}$ through fortified vermicompost $+75 \%$ $\mathrm{N}$ through fertilizer $\left(\mathrm{T}_{5}\right)$ and recommended dose of fertilizer $\left(T_{7}\right)$ had higher biological yield during both the years of experimentation. The results of present study confirm the earlier findings of Ravi et al., (2012). Fertility treatments applied in wheat did not have any significant effect on biological yield of maize during both the years.

\section{Grain yield and straw yield}

The data on the grain yield, straw yield of wheat have been given in Table 9. Residual effect of treatments applied in maize could not bring about significant variation in the grain and straw yield and harvest index of wheat during both the years of experimentation.

However, fertilizer levels applied in wheat significantly influenced the grain and straw yield of wheat during both the years. Application of $100 \%$ recommended dose of fertilizers $\left(\mathrm{F}_{3}\right)$ resulted in significantly highest grain and straw yield of wheat followed by $75 \%$ recommended dose of fertilizers $\left(\mathrm{F}_{2}\right)$ during both the years of experimentation. The lowest grain and straw yield of wheat was recorded with $50 \%$ recommended dose of fertilizers $\left(\mathrm{F}_{1}\right)$ during both the years. The harvest index of wheat was not significantly affected due to fertility treatments in wheat. The increase in grain yield due to $100 \%$ recommended dose of fertilizers over $75 \%$ and $50 \%$ recommended dose of fertilizers was $12.65 \%$ and $23.36 \%$ during 2015-16 and 
$7.54 \%$ and $22.03 \%$ during 2016-17, respectively. The grain yield of wheat is a resultant product of number of spikes per unit area, number of grains per spike and weight of individual grains (Arnon 1975). The application of $100 \%$ RDF resulted in more ear bearing tillers, more number of grains per ear and weight of 1000-grains in present study, resulting in higher grain yield. Similarly, higher grain yield of wheat with $100 \%$ RDF application have also been reported by Malghani (2010); Tababtabaei and Ranjbar (2012); Siddiqui et al., (2013); Dwivedi et al., (2014) and Kumar (2015). The different fertility levels applied directly to wheat did not influence the harvest index during both the years of investigations. Fertility treatments to wheat brought about significant variation in biological yield (grain+straw) of wheat during both the years (Fig. 2a and b). The interaction between nutrient management treatment in maize and wheat could not significantly affect the grain, straw and biological yield and harvest index of wheat during both the years of experimentation.

Table.1 Initial composition of FYM, vermicompost and fortified vermicompost used in the experiment

\begin{tabular}{|c|c|c|c|c|c|c|}
\hline \multirow[t]{2}{*}{ Parameter } & \multicolumn{3}{|c|}{ Maize 2015} & \multicolumn{3}{|c|}{ Maize 2016} \\
\hline & FYM & $\begin{array}{l}\text { Vermi- } \\
\text { compost }\end{array}$ & $\begin{array}{l}\text { Fortified vermi- } \\
\text { compost }\end{array}$ & FYM & $\begin{array}{c}\text { Vermi- } \\
\text { compost }\end{array}$ & $\begin{array}{l}\text { Fortified vermi- } \\
\text { compost }\end{array}$ \\
\hline Nitrogen $(\%)$ & 0.91 & 1.80 & 2.02 & 0.93 & 1.90 & 2.12 \\
\hline Phosphorus (\%) & 0.33 & 0.70 & 0.85 & 0.35 & 0.90 & 0.87 \\
\hline Potassium (\%) & 0.67 & 1.24 & 1.30 & 0.65 & 1.30 & 1.27 \\
\hline
\end{tabular}

Table.2 Treatment effects on NPK content (\%) in maize grain and stover during, 2015 and 2016

\begin{tabular}{|c|c|c|c|c|c|c|c|c|c|c|c|c|c|}
\hline \multirow{2}{*}{\multicolumn{2}{|c|}{ Treatment }} & \multicolumn{4}{|c|}{ Nitrogen content (\%) } & \multicolumn{4}{|c|}{ Phosphorus content (\%) } & \multicolumn{4}{|c|}{ Potassium content $(\%)$} \\
\hline & & \multicolumn{2}{|c|}{ Grain } & \multicolumn{2}{|c|}{ Stover } & \multicolumn{2}{|c|}{ Grain } & \multicolumn{2}{|c|}{ Stover } & \multicolumn{2}{|c|}{ Grain } & \multicolumn{2}{|c|}{ Stover } \\
\hline \multicolumn{2}{|c|}{ In maize } & 2015 & 2016 & 2015 & 2016 & 2015 & 2016 & 2015 & 2016 & $\overline{2015}$ & 2016 & 2015 & 2016 \\
\hline $\mathbf{T}_{1}$ & Fertilizer $_{50 \mathrm{~N}}$ & 1.15 & 1.14 & 0.88 & 0.48 & 0.44 & 0.46 & 0.08 & 0.10 & 0.53 & 0.54 & 1.30 & 1.28 \\
\hline $\mathbf{T}_{2}$ & $\begin{array}{l}\text { Forti. } \text { VC }_{50 \mathrm{~N}}+ \\
\text { Fertilizer }_{50 \mathrm{~N}}\end{array}$ & 1.16 & 1.15 & 0.91 & 0.46 & 0.48 & 0.48 & 0.09 & 0.11 & 0.55 & 0.54 & 1.35 & 1.30 \\
\hline $\mathbf{T}_{\mathbf{3}}$ & $\begin{array}{l}\mathrm{VC}_{50 \mathrm{~N}}+ \\
\text { Fertilizer }_{50 \mathrm{~N}}\end{array}$ & 1.14 & 1.14 & 0.89 & 0.47 & 0.46 & 0.46 & 0.08 & 0.10 & 0.55 & 0.56 & 1.33 & 1.31 \\
\hline $\mathbf{T}_{4}$ & $\begin{array}{l}\mathrm{FYM}_{25 \mathrm{~N}}+ \\
\text { Fertilizer }_{75 \mathrm{~N}}\end{array}$ & 1.17 & 1.16 & 0.92 & 0.47 & 0.47 & 0.46 & 0.09 & 0.09 & 0.56 & 0.55 & 1.33 & 1.29 \\
\hline $\mathbf{T}_{5}$ & $\begin{array}{l}\text { Forti. } \text { VC }_{25 \mathrm{~N}}+ \\
\text { Fertilizer }_{75 \mathrm{~N}}\end{array}$ & 1.19 & 1.16 & 0.93 & 0.46 & 0.47 & 0.47 & 0.09 & 0.10 & 0.56 & 0.56 & 1.37 & 1.31 \\
\hline $\mathbf{T}_{6}$ & $\begin{array}{l}\mathrm{VC}_{25 \mathrm{~N}}+ \\
\text { Fertilizer }_{75 \mathrm{~N}}\end{array}$ & 1.16 & 1.15 & 0.92 & 0.48 & 0.46 & 0.47 & 0.08 & 0.09 & 0.57 & 0.56 & 1.36 & 1.31 \\
\hline $\mathbf{T}_{7}$ & RDF & 1.17 & 1.17 & 0.93 & 0.44 & 0.48 & 0.48 & 0.10 & 0.11 & 0.58 & 0.57 & 1.38 & 1.32 \\
\hline \multicolumn{2}{|c|}{ SEm \pm} & 0.02 & 0.02 & 0.03 & 0.01 & 0.02 & 0.02 & 0.01 & 0.01 & 0.01 & 0.018 & 0.02 & 0.02 \\
\hline \multicolumn{2}{|c|}{$\mathrm{CD}(\mathrm{P}=0.05)$} & NS & NS & NS & NS & $\mathrm{NS}$ & NS & NS & NS & NS & NS & NS & NS \\
\hline \multicolumn{14}{|c|}{ In wheat } \\
\hline $\mathbf{F}_{1}$ & $50 \%$ RDF & - & 1.15 & - & 0.89 & - & 0.47 & - & 0.09 & - & 0.54 & - & 1.29 \\
\hline $\mathbf{F}_{2}$ & $75 \% \mathrm{RDF}$ & - & 1.15 & - & 0.88 & - & 0.46 & - & 0.10 & - & 0.56 & - & 1.31 \\
\hline$F_{3}$ & $100 \% \mathrm{RDF}$ & - & 1.16 & - & 0.89 & - & 0.47 & - & 0.10 & - & 0.56 & - & 1.31 \\
\hline \multicolumn{2}{|c|}{ SEm \pm} & - & 0.01 & - & 0.01 & - & 0.01 & - & 0.01 & - & 0.01 & - & 0.01 \\
\hline \multicolumn{2}{|c|}{$\mathrm{CD}(\mathrm{P}=\mathbf{0 . 0 5})$} & - & NS & - & NS & - & NS & - & NS & - & NS & - & NS \\
\hline
\end{tabular}

FYM= Farm yard manure, Forti = Fortified, 50N= 50\% Nitrogen, VC= Vermicompost, RDF= Recommended dose of fertilizer 
Table.3.1 Treatment effects on nitrogen uptake by grain, stover and total uptake $\quad\left(\mathrm{kg} \mathrm{ha}^{-1}\right)$ in maize during, 2015 and 2016

\begin{tabular}{|c|c|c|c|c|c|c|c|}
\hline \multirow{2}{*}{\multicolumn{2}{|c|}{ Treatment }} & \multicolumn{6}{|c|}{ Nitrogen uptake $\left(\mathrm{kg} \mathrm{ha}^{-1}\right)$} \\
\hline & & \multicolumn{2}{|c|}{ Grain } & \multicolumn{2}{|c|}{ Stover } & \multicolumn{2}{|c|}{ Total } \\
\hline \multicolumn{2}{|c|}{ In maize } & 2015 & 2016 & 2015 & 2016 & 2015 & 2016 \\
\hline $\mathbf{T}_{1}$ & $\mathrm{FYM}_{50 \mathrm{~N}}+$ Fertilizer $_{50 \mathrm{~N}}$ & 41.5 & 43.5 & 47.6 & 49.3 & 89.1 & 92.9 \\
\hline $\mathbf{T}_{2}$ & Forti. $\mathrm{VC}_{50 \mathrm{~N}}+$ Fertilizer $_{50 \mathrm{~N}}$ & 44.7 & 46.6 & 52.4 & 53.1 & 97.1 & 99.6 \\
\hline $\mathbf{T}_{3}$ & $\mathrm{VC}_{50 \mathrm{~N}}+$ Fertilizer $_{50 \mathrm{~N}}$ & 43.3 & 43.9 & 50.2 & 51.2 & 93.5 & 95.1 \\
\hline $\mathbf{T}_{4}$ & $\mathrm{FYM}_{25 \mathrm{~N}}+$ Fertilizer $_{75 \mathrm{~N}}$ & 45.2 & 47.5 & 53.0 & 51.7 & 98.2 & 99.2 \\
\hline $\mathbf{T}_{5}$ & Forti. VC $_{25 \mathrm{~N}}+$ Fertilizer $_{75 \mathrm{~N}}$ & 51.2 & 50.0 & 57.9 & 56.8 & 109.1 & 106.8 \\
\hline $\mathbf{T}_{6}$ & $\mathrm{VC}_{25 \mathrm{~N}}+$ Fertilizer $_{75 \mathrm{~N}}$ & 48.6 & 48.4 & 56.1 & 56.2 & 104.7 & 104.6 \\
\hline $\mathbf{T}_{7}$ & RDF & 50.0 . & 51.6 & 58.3 & 59.4 & 108.3 & 111.0 \\
\hline \multicolumn{2}{|c|}{ SEm \pm} & 1.83 & 1.66 & 2.59 & 2.24 & 3.66 & 3.38 \\
\hline \multicolumn{2}{|c|}{$\mathrm{CD}(\mathrm{P}=0.05)$} & 5.65 & 5.12 & 7.98 & 6.90 & 11.3 & 10.4 \\
\hline \multicolumn{8}{|c|}{ In wheat } \\
\hline $\mathbf{F}_{1}$ & $50 \% \mathrm{RDF}$ & - & 46.4 & - & 53.3 & - & 99.8 \\
\hline $\mathbf{F}_{2}$ & $75 \%$ RDF & - & 47.4 & - & 53.6 & - & 101.1 \\
\hline $\mathbf{F}_{3}$ & $100 \%$ RDF & - & 48.2 & - & 55.0 & - & 103.2 \\
\hline \multicolumn{2}{|c|}{ SEm \pm} & - & 1.08 & - & 1.17 & - & 1.84 \\
\hline \multicolumn{2}{|c|}{$\mathrm{CD}(\mathrm{P}=0.05)$} & - & NS & - & NS & - & NS \\
\hline
\end{tabular}

FYM= Farm yard manure, Forti= Fortified, 50N= 50\% Nitrogen, VC= Vermicompost, RDF= Recommended dose of fertilizer

Table3.2 Treatment effects on phosphorus uptake by grain, stover and total uptake $\left(\mathrm{kg} \mathrm{ha}^{-1}\right)$ in maize during, 2015 and 2016

\begin{tabular}{|c|c|c|c|c|c|c|c|}
\hline \multirow{2}{*}{\multicolumn{2}{|c|}{ Treatment }} & \multicolumn{6}{|c|}{ Phosphorus uptake $\left(\mathrm{kg} \mathrm{ha}^{-1}\right)$} \\
\hline & & \multicolumn{2}{|c|}{ Grain } & \multicolumn{2}{|c|}{ Stover } & \multicolumn{2}{|c|}{ Total } \\
\hline \multicolumn{2}{|c|}{ In maize } & 2015 & 2016 & 2015 & 2016 & 2015 & 2016 \\
\hline $\mathbf{T}_{1}$ & $\mathrm{FYM}_{50 \mathrm{~N}}+$ Fertilizer $_{50 \mathrm{~N}}$ & 15.9 & 17.6 & 4.5 & 5.7 & 20.4 & 21.6 \\
\hline $\mathbf{T}_{2}$ & Forti. VC $_{50 \mathrm{~N}}+$ Fertilizer $_{50 \mathrm{~N}}$ & 18.5 & 19.4 & 5.4 & 6.6 & 23.9 & 25.2 \\
\hline $\mathbf{T}_{3}$ & $\mathrm{VC}_{50 \mathrm{~N}}+$ Fertilizer $_{50 \mathrm{~N}}$ & 17.5 & 17.7 & 4.7 & 5.8 & 22.2 & 23.3 \\
\hline $\mathbf{T}_{4}$ & $\mathrm{FYM}_{25 \mathrm{~N}}+$ Fertilizer $_{75 \mathrm{~N}}$ & 18.1 & 18.8 & 5.4 & 5.4 & 23.5 & 23.4 \\
\hline $\mathbf{T}_{5}$ & Forti. VC $_{25 \mathrm{~N}}+$ Fertilizer $_{75 \mathrm{~N}}$ & 20.2 & 20.2 & 5.4 & 6.4 & 25.6 & 26.6 \\
\hline $\mathbf{T}_{6}$ & $\mathrm{VC}_{25 \mathrm{~N}}+$ Fertilizer $_{75 \mathrm{~N}}$ & 19.0 & 19.8 & 5.1 & 5.6 & 24.1 & 24.7 \\
\hline $\mathbf{T}_{7}$ & RDF & 20.7 & 21.2 & 6.1 & 7.2 & 26.7 & 27.9 \\
\hline \multicolumn{2}{|c|}{ SEm \pm} & 1.08 & 0.89 & 0.40 & 0.48 & 1.35 & 1.16 \\
\hline \multicolumn{2}{|c|}{$\mathrm{CD}(\mathrm{P}=\mathbf{0 . 0 5})$} & 3.31 & 2.74 & 1.22 & 1.46 & 4.16 & 3.56 \\
\hline \multicolumn{8}{|c|}{ In wheat } \\
\hline $\mathbf{F}_{1}$ & $50 \% \mathrm{RDF}$ & - & 18.97 & - & 5.39 & - & 10.8 \\
\hline $\mathbf{F}_{2}$ & $75 \% \mathrm{RDF}$ & - & 18.97 & - & 6.10 & - & 12.2 \\
\hline $\mathbf{F}_{3}$ & $100 \% \mathrm{RDF}$ & - & 19.53 & - & 6.17 & - & 12.3 \\
\hline \multicolumn{2}{|c|}{ SEm \pm} & - & 0.58 & - & 0.40 & - & 0.82 \\
\hline \multicolumn{2}{|c|}{$\mathrm{CD}(\mathrm{P}=0.05)$} & - & NS & - & NS & - & NS \\
\hline
\end{tabular}

FYM= Farm yard manure, Forti= Fortified, 50N= 50\% Nitrogen, VC= Vermicompost, RDF= Recommended dose of fertilizer 
Table.3.3 Treatment effects on potassium uptake by grain, stover and total uptake $\left(\mathrm{kg} \mathrm{ha}^{-1}\right)$ in maize during, 2015 and 2016

\begin{tabular}{|c|c|c|c|c|c|c|c|}
\hline \multirow{2}{*}{\multicolumn{2}{|c|}{ Treatment }} & \multicolumn{6}{|c|}{ Potassium uptake $\left(\mathrm{kg} \mathrm{ha}^{-1}\right)$} \\
\hline & & \multicolumn{2}{|c|}{ Grain } & \multicolumn{2}{|c|}{ Stover } & \multicolumn{2}{|c|}{ Total } \\
\hline \multicolumn{2}{|c|}{ In maize } & 2015 & 2016 & 2015 & 2016 & 2015 & 2016 \\
\hline $\mathbf{T}_{1}$ & FYM $_{50 \mathrm{~N}}+$ Fertilizer $_{50 \mathrm{~N}}$ & 19.3 & 20.6 & 70.5 & 72.6 & 89.8 & 93.2 \\
\hline $\mathbf{T}_{2}$ & Forti. $\mathrm{VC}_{50 \mathrm{~N}}+$ Fertilizer $_{50 \mathrm{~N}}$ & 21.3 & 21.9 & 78.5 & 78.4 & 99.8 & 100.3 \\
\hline $\mathbf{T}_{3}$ & $\mathrm{VC}_{50 \mathrm{~N}}+$ Fertilizer $_{50 \mathrm{~N}}$ & 21.0 & 21.6 & 74.4 & 76.2 & 95.4 & 97.8 \\
\hline $\mathbf{T}_{4}$ & $\mathrm{FYM}_{25 \mathrm{~N}}+$ Fertilizer $_{75 \mathrm{~N}}$ & 21.7 & 22.5 & 76.8 & 76.7 & 98.5 & 99.2 \\
\hline $\mathbf{T}_{5}$ & Forti. $\mathrm{VC}_{25 \mathrm{~N}}+$ Fertilizer $_{75 \mathrm{~N}}$ & 24.2 & 24.1 & 85.2 & 83.6 & 109.4 & 107.8 \\
\hline $\mathbf{T}_{6}$ & $\mathrm{VC}_{25 \mathrm{~N}}+$ Fertilizer $_{75 \mathrm{~N}}$ & 23.6 & 23.6 & 82.4 & 81.8 & 106.0 & 105.4 \\
\hline $\mathbf{T}_{7}$ & $\mathrm{RDF}$ & 24.9 & 25.2 & 86.8 & 86.1 & 111.7 & 111.3 \\
\hline \multicolumn{2}{|c|}{ SEm \pm} & 0.99 & 1.18 & 3.31 & 2.89 & 3.80 & 3.37 \\
\hline \multicolumn{2}{|c|}{$\mathrm{CD}(\mathbf{P}=0.05)$} & 3.06 & 3.63 & 10.21 & 8.91 & 11.7 & 10.40 \\
\hline \multicolumn{8}{|c|}{ In wheat } \\
\hline $\mathbf{F}_{1}$ & $50 \% \mathrm{RDF}$ & - & 21.8 & - & 77.3 & - & 99.1 \\
\hline $\mathbf{F}_{2}$ & $75 \% \mathrm{RDF}$ & - & 23.1 & - & 79.9 & - & 103.0 \\
\hline $\mathbf{F}_{3}$ & $100 \% \mathrm{RDF}$ & - & 23.3 & - & 80.9 & - & 104.2 \\
\hline \multicolumn{2}{|c|}{ SEm \pm} & - & 0.68 & - & 1.88 & - & 2.08 \\
\hline \multicolumn{2}{|c|}{$\mathrm{CD}(\mathrm{P}=\mathbf{0 . 0 5})$} & - & NS & - & NS & - & NS \\
\hline
\end{tabular}

FYM= Farm yard manure, Forti= Fortified, 50N= 50\% Nitrogen, VC= Vermicompost, RDF= Recommended dose of fertilizer

Table.4 Treatment effects on protein content (\%) in maize grain during, 2015 and 2016

\begin{tabular}{|c|c|c|c|}
\hline \multirow{2}{*}{\multicolumn{2}{|c|}{$\begin{array}{l}\text { Treatment } \\
\text { In maize }\end{array}$}} & \multicolumn{2}{|c|}{ Protein content (\%) } \\
\hline & & 2015 & 2016 \\
\hline $\mathbf{T}_{1}$ & $\mathrm{FYM}_{50 \mathrm{~N}}+$ Fertilizer $_{50 \mathrm{~N}}$ & 7.17 & 7.13 \\
\hline $\mathbf{T}_{2}$ & Forti. VC $_{50 \mathrm{~N}}+$ Fertilizer $_{50 \mathrm{~N}}$ & 7.23 & 7.19 \\
\hline $\mathbf{T}_{3}$ & $\mathrm{VC}_{50 \mathrm{~N}}+$ Fertilizer $_{50 \mathrm{~N}}$ & 7.15 & 7.13 \\
\hline $\mathbf{T}_{4}$ & $\mathrm{FYM}_{25 \mathrm{~N}}+$ Fertilizer $_{75 \mathrm{~N}}$ & 7.29 & 7.25 \\
\hline $\mathbf{T}_{5}$ & Forti. $\mathrm{VC}_{25 \mathrm{~N}}+$ Fertilizer $_{75 \mathrm{~N}}$ & 7.46 & 7.25 \\
\hline$T_{6}$ & $\mathrm{VC}_{25 \mathrm{~N}}+$ Fertilizer $_{75 \mathrm{~N}}$ & 7.27 & 7.19 \\
\hline $\mathbf{T}_{7}$ & $\mathrm{RDF}$ & 7.31 & 7.31 \\
\hline \multicolumn{2}{|c|}{ SEm \pm} & 0.09 & 0.15 \\
\hline \multicolumn{2}{|c|}{$\mathrm{CD}(\mathrm{P}=0.05)$} & NS & NS \\
\hline \multicolumn{4}{|c|}{ In wheat } \\
\hline $\mathbf{F}_{1}$ & $50 \% \mathrm{RDF}$ & - & 7.19 \\
\hline $\mathbf{F}_{2}$ & $75 \% \mathrm{RDF}$ & - & 7.19 \\
\hline $\mathbf{F}_{3}$ & $100 \% \mathrm{RDF}$ & - & 7.25 \\
\hline \multicolumn{2}{|c|}{ SEm \pm} & - & 0.07 \\
\hline \multicolumn{2}{|c|}{$\mathrm{CD}(\mathrm{P}=0.05)$} & - & NS \\
\hline
\end{tabular}

FYM= Farm yard manure, Forti $=$ Fortified, $50 \mathrm{~N}=50 \%$ Nitrogen, $\mathrm{VC}=$ Vermicompost, RDF= Recommended dose of fertilizer 
Table.5 Treatment effects on NPK content (\%) in wheat grain and straw during, 2015-16 and 2016-17

\begin{tabular}{|c|c|c|c|c|c|c|c|c|c|c|c|c|c|}
\hline \multirow{2}{*}{\multicolumn{2}{|c|}{ Treatment }} & \multicolumn{4}{|c|}{ Nitrogen content $(\%)$} & \multicolumn{4}{|c|}{ Phosphorus content (\%) } & \multicolumn{4}{|c|}{ Potassium content $(\%)$} \\
\hline & & \multicolumn{2}{|c|}{ Grain } & \multicolumn{2}{|c|}{ Straw } & \multicolumn{2}{|c|}{ Grain } & \multicolumn{2}{|c|}{ Straw } & \multicolumn{2}{|c|}{ Grain } & \multicolumn{2}{|c|}{ Straw } \\
\hline \multicolumn{2}{|l|}{ In maize } & $2015-16$ & $2016-17$ & $2015-16$ & $2016-17$ & $2015-16$ & $2016-17$ & $2015-16$ & $2016-17$ & $2015-16$ & $2016-17$ & $2015-16$ & $2016-17$ \\
\hline $\mathbf{T}_{1}$ & $\begin{array}{l}\text { FYM }_{50 \mathrm{~N}}+ \\
\text { Fertilizer }_{50 \mathrm{~N}}\end{array}$ & 1.50 & 1.43 & 0.46 & 0.42 & 0.330 & 0.324 & 0.072 & 0.073 & 0.280 & 0.264 & 0.71 & 0.74 \\
\hline $\mathbf{T}_{2}$ & $\begin{array}{l}\text { Forti. } \mathrm{VC}_{50 \mathrm{~N}}+ \\
\text { Fertilizer }_{50 \mathrm{~N}}\end{array}$ & 1.48 & 1.45 & 0.45 & 0.43 & 0.340 & 0.332 & 0.064 & 0.070 & 0.270 & 0.258 & 0.73 & 0.75 \\
\hline $\mathbf{T}_{3}$ & $\begin{array}{l}\mathrm{VC}_{50 \mathrm{~N}}+ \\
\text { Fertilizer }_{50 \mathrm{~N}}\end{array}$ & 1.49 & 1.46 & 0.45 & 0.42 & 0.340 & 0.323 & 0.066 & 0.072 & 0.270 & 0.263 & 0.72 & 0.74 \\
\hline $\mathbf{T}_{4}$ & $\begin{array}{l}\text { FYM }_{25 \mathrm{~N}}+ \\
\text { Fertilizer }_{75 \mathrm{~N}}\end{array}$ & 1.51 & 1.44 & 0.47 & 0.43 & 0.330 & 0.314 & 0.070 & 0.073 & 0.290 & 0.270 & 0.72 & 0.73 \\
\hline $\mathbf{T}_{5}$ & $\begin{array}{l}\text { Forti. } \mathrm{VC}_{25 \mathrm{~N}}+ \\
\text { Fertilizer }_{75 \mathrm{~N}}\end{array}$ & 1.50 & 1.45 & 0.46 & 0.43 & 0.340 & 0.324 & 0.071 & 0.069 & 0.270 & 0.263 & 0.71 & 0.74 \\
\hline $\mathbf{T}_{6}$ & $\begin{array}{l}\mathrm{VC}_{25 \mathrm{~N}}+ \\
\text { Fertilizer }_{75 \mathrm{~N}}\end{array}$ & 1.49 & 1.44 & 0.46 & 0.42 & 0.330 & 0.320 & 0.069 & 0.072 & 0.280 & 0.268 & 0.72 & 0.72 \\
\hline $\mathbf{T}_{7}$ & RDF & 1.48 & 1.46 & 0.45 & 0.42 & 0.330 & 0.322 & 0.068 & 0.069 & 0.280 & 0.273 & 0.73 & 0.73 \\
\hline \multicolumn{2}{|l|}{ SEm \pm} & 0.013 & 0.017 & 0.016 & 0.012 & 0.007 & 0.011 & 0.005 & 0.006 & 0.010 & 0.009 & 0.014 & 0.016 \\
\hline \multicolumn{2}{|l|}{$\mathrm{CD}(\mathrm{P}=0.05)$} & NS & NS & NS & NS & NS & NS & NS & NS & NS & NS & NS & NS \\
\hline \multicolumn{14}{|l|}{ In wheat } \\
\hline $\mathbf{F}_{1}$ & $50 \%$ RDF & 1.46 & 1.42 & 0.44 & 0.41 & 0.320 & 0.308 & 0.067 & 0.070 & 0.260 & 0.257 & 0.70 & 0.72 \\
\hline $\mathbf{F}_{2}$ & $75 \%$ RDF & 1.50 & 1.45 & 0.46 & 0.43 & 0.340 & 0.326 & 0.070 & 0.072 & 0.280 & 0.267 & 0.73 & 0.74 \\
\hline $\mathbf{F}_{3}$ & $100 \% \mathrm{RDF}$ & 1.52 & 1.47 & 0.47 & 0.44 & 0.340 & 0.334 & 0.070 & 0.071 & 0.290 & 0.273 & 0.73 & 0.75 \\
\hline \multicolumn{2}{|l|}{ SEm \pm} & 0.022 & 0.024 & 0.012 & 0.010 & 0.008 & 0.019 & 0.004 & 0.008 & 0.016 & 0.016 & 0.015 & 0.021 \\
\hline \multicolumn{2}{|l|}{$\mathrm{CD}(\mathrm{P}=0.05)$} & NS & NS & NS & NS & NS & NS & NS & NS & NS & NS & NS & NS \\
\hline
\end{tabular}

FYM= Farm yard manure, Forti=Fortified, $50 \mathrm{~N}=50 \%$ Nitrogen, $\mathrm{VC}=$ Vermicompost, $\mathrm{RDF}=$ Recommended dose of fertilizer 
Table.6.1 Treatment effects on nitrogen uptake $\left(\mathrm{kg} \mathrm{ha}^{-1}\right)$ in wheat grain, straw and total, during, 2015-16 and 2016-17

\begin{tabular}{|c|c|c|c|c|c|c|c|}
\hline \multicolumn{2}{|c|}{ Treatment } & \multicolumn{2}{|c|}{ Grain } & \multicolumn{2}{|c|}{ Straw } & \multicolumn{2}{|c|}{ Total } \\
\hline \multicolumn{2}{|c|}{ In maize } & $\begin{array}{c}2015- \\
16\end{array}$ & $\begin{array}{c}\text { 2016- } \\
17\end{array}$ & $\begin{array}{c}2015- \\
16\end{array}$ & $\begin{array}{c}2016- \\
17\end{array}$ & $\begin{array}{c}2015- \\
16\end{array}$ & $\begin{array}{c}2016- \\
17\end{array}$ \\
\hline $\mathbf{T}_{1}$ & $\mathrm{FYM}_{50 \mathrm{~N}}+$ Fertilizer $_{50 \mathrm{~N}}$ & 54.6 & 55.1 & 23.6 & 24.8 & 78.2 & 79.9 \\
\hline $\mathbf{T}_{2}$ & Forti. $\mathrm{VC}_{50 \mathrm{~N}}+$ Fertilizer $_{50 \mathrm{~N}}$ & 53.4 & 54.9 & 22.6 & 25.1 & 76.0 & 80.0 \\
\hline $\mathbf{T}_{3}$ & $\mathrm{VC}_{50 \mathrm{~N}}+$ Fertilizer $_{50 \mathrm{~N}}$ & 52.4 & 54.7 & 22.7 & 24.4 & 75.1 & 79.1 \\
\hline $\mathbf{T}_{4}$ & $\mathrm{FYM}_{25 \mathrm{~N}}+$ Fertilizer $_{75 \mathrm{~N}}$ & 54.1 & 54.1 & 24.0 & 24.9 & 77.7 & 79.0 \\
\hline $\mathbf{T}_{5}$ & Forti. $\mathrm{VC}_{25 \mathrm{~N}}+$ Fertilizer $_{75 \mathrm{~N}}$ & 53.0 & 53.5 & 22.9 & 24.3 & 75.8 & 77.8 \\
\hline $\mathbf{T}_{6}$ & $\mathrm{VC}_{25 \mathrm{~N}}+$ Fertilizer $_{75 \mathrm{~N}}$ & 52.1 & 53.0 & 23.0 & 23.6 & 75.0 & 76.6 \\
\hline $\mathbf{T}_{7}$ & RDF & 51.1 & 53.2 & 22.1 & 23.5 & 73.2 & 76.7 \\
\hline \multicolumn{2}{|c|}{ SEm \pm} & 1.48 & 1.28 & 0.72 & 0.82 & 1.83 & 1.69 \\
\hline \multicolumn{2}{|c|}{$\mathrm{CD}(\mathrm{P}=0.05)$} & NS & NS & NS & NS & NS & NS \\
\hline \multicolumn{8}{|c|}{ In wheat } \\
\hline $\mathbf{F}_{1}$ & $50 \% \mathrm{RDF}$ & 46.7 & 47.4 & 20.0 & 21.5 & 66.7 & 68.9 \\
\hline $\mathbf{F}_{2}$ & $75 \% \mathrm{RDF}$ & 52.5 & 55.0 & 22.7 & 24.8 & 75.2 & 79.8 \\
\hline $\mathbf{F}_{3}$ & $100 \% \mathrm{RDF}$ & 60.0 & 59.9 & 26.1 & 27.0 & 86.0 & 86.9 \\
\hline \multicolumn{2}{|c|}{ SEm \pm} & 1.34 & 1.56 & 0.57 & 0.74 & 1.68 & 1.94 \\
\hline \multicolumn{2}{|c|}{$\mathrm{CD}(\mathrm{P}=0.05)$} & 3.88 & 4.5 & 1.65 & 2.1 & 4.9 & 5.6 \\
\hline
\end{tabular}

FYM= Farm yard manure, Forti=Fortified, 50N = 50\% Nitrogen, VC= Vermicompost, RDF= Recommended dose of fertilizer

Table.6.2 Treatment effects on phosphorus uptake $\left(\mathrm{kg} \mathrm{ha}^{-1}\right)$ in wheat grain, straw and total during, 2015-16 and 2016-17

\begin{tabular}{|c|c|c|c|c|c|c|c|}
\hline \multirow{2}{*}{\multicolumn{2}{|c|}{$\begin{array}{l}\text { Treatment } \\
\text { In maize }\end{array}$}} & \multicolumn{2}{|c|}{ Grain } & \multicolumn{2}{|c|}{ Straw } & \multicolumn{2}{|c|}{ Total } \\
\hline & & \multirow{2}{*}{$\begin{array}{c}2015-16 \\
12.0\end{array}$} & \multirow{2}{*}{$\begin{array}{c}\text { 2016-17 } \\
12.47\end{array}$} & \multirow{2}{*}{$\begin{array}{c}2015-16 \\
3.7\end{array}$} & \multirow{2}{*}{$\begin{array}{c}\text { 2016-17 } \\
4.30\end{array}$} & \multirow{2}{*}{$\begin{array}{c}2015-16 \\
15.7\end{array}$} & \multirow{2}{*}{$\begin{array}{c}2016-17 \\
16.8 \\
\end{array}$} \\
\hline $\mathbf{T}_{1}$ & FYM $_{50 \mathrm{~N}}+$ Fertilizer $_{50 \mathrm{~N}}$ & & & & & & \\
\hline $\mathbf{T}_{2}$ & Forti. $\mathrm{VC}_{50 \mathrm{~N}}+$ Fertilizer $_{50 \mathrm{~N}}$ & 12.3 & 12.57 & 3.2 & 4.10 & 15.5 & 16.7 \\
\hline $\mathbf{T}_{3}$ & VC $_{50 \mathrm{~N}}+$ Fertilizer $_{50 \mathrm{~N}}$ & 12.0 & 12.09 & 3.3 & 4.20 & 15.3 & 16.3 \\
\hline $\mathbf{T}_{4}$ & $\mathrm{FYM}_{25 \mathrm{~N}}+$ Fertilizer $_{75 \mathrm{~N}}$ & 11.8 & 11.79 & 3.5 & 4.20 & 15.4 & 16.0 \\
\hline $\mathbf{T}_{5}$ & Forti. $\mathrm{VC}_{25 \mathrm{~N}}+$ Fertilizer $_{75 \mathrm{~N}}$ & 12.0 & 11.95 & 3.5 & 3.90 & 15.6 & 15.9 \\
\hline$T_{6}$ & VC $_{25 \mathrm{~N}}+$ Fertilizer $_{75 \mathrm{~N}}$ & 11.5 & 11.78 & 3.4 & 4.00 & 15.0 & 15.8 \\
\hline $\mathbf{T}_{7}$ & RDF & 11.4 & 11.74 & 3.4 & 3.90 & 14.7 & 15.6 \\
\hline \multicolumn{2}{|c|}{ SEm \pm} & 0.36 & 0.32 & 0.22 & 0.26 & 0.48 & 0.52 \\
\hline \multicolumn{2}{|c|}{$\mathrm{CD}(\mathbf{P}=0.05)$} & NS & NS & NS & NS & NS & NS \\
\hline \multicolumn{8}{|c|}{ In wheat } \\
\hline $\mathbf{F}_{1}$ & $50 \% \mathrm{RDF}$ & 10.2 & 10.29 & 3.0 & 3.70 & 13.3 & 14.0 \\
\hline $\mathbf{F}_{2}$ & $75 \% \mathrm{RDF}$ & 11.9 & 12.36 & 3.5 & 4.20 & 15.4 & 16.6 \\
\hline $\mathbf{F}_{3}$ & $100 \% \mathrm{RDF}$ & 13.4 & 13.61 & 3.9 & 4.40 & 17.3 & 18.0 \\
\hline \multicolumn{2}{|c|}{ SEm \pm} & 0.27 & 0.42 & 0.18 & 0.14 & 0.39 & 0.46 \\
\hline \multicolumn{2}{|c|}{$\mathrm{CD}(\mathrm{P}=0.05)$} & 0.78 & 1.22 & 0.52 & 0.40 & 1.13 & 1.33 \\
\hline
\end{tabular}

FYM= Farm yard manure, Forti=Fortified, $50 \mathrm{~N}=50 \%$ Nitrogen, $\mathrm{VC}=$ Vermicompost, $\mathrm{RDF}=$ Recommended dose of fertilizer 
Table.6.3 Treatment effects on potassium uptake $\left(\mathrm{kg} \mathrm{ha}^{-1}\right)$ in wheat grain, straw and total during 2015-16 and 2016-17

\begin{tabular}{|c|c|c|c|c|c|c|c|}
\hline \multirow{2}{*}{\multicolumn{2}{|c|}{$\begin{array}{l}\text { Treatment } \\
\text { In maize }\end{array}$}} & \multicolumn{2}{|c|}{ Grain } & \multicolumn{2}{|c|}{ Straw } & \multicolumn{2}{|c|}{ Total } \\
\hline & & \multirow{2}{*}{$\begin{array}{c}2015-16 \\
12.0\end{array}$} & \multirow{2}{*}{$\begin{array}{c}2016-17 \\
12.47\end{array}$} & \multirow{2}{*}{$\begin{array}{c}2015-16 \\
36.5\end{array}$} & \multirow{2}{*}{$\begin{array}{c}2016-17 \\
43.7\end{array}$} & \multirow{2}{*}{$\begin{array}{c}2015-16 \\
46.7 \\
\end{array}$} & \multirow{2}{*}{$\begin{array}{c}2016-17 \\
53.9 \\
\end{array}$} \\
\hline $\mathbf{T}_{1}$ & FYM $_{50 \mathrm{~N}}+$ Fertilizer $_{50 \mathrm{~N}}$ & & & & & & \\
\hline $\mathbf{T}_{2}$ & Forti. $\mathrm{VC}_{50 \mathrm{~N}}+$ Fertilizer $_{50 \mathrm{~N}}$ & 12.3 & 12.57 & 36.6 & 43.9 & 46.3 & 53.7 \\
\hline $\mathbf{T}_{\mathbf{3}}$ & VC $_{50 \mathrm{~N}}+$ Fertilizer $_{50 \mathrm{~N}}$ & 12.0 . & 12.09 & 36.3 & 43.0 & 45.8 & 52.9 \\
\hline $\mathbf{T}_{4}$ & $\mathrm{FYM}_{25 \mathrm{~N}}+$ Fertilizer $_{75 \mathrm{~N}}$ & 11.8 & 11.79 & 36.1 & 42.2 & 46.5 & 52.3 \\
\hline $\mathbf{T}_{5}$ & Forti. $\mathrm{VC}_{25 \mathrm{~N}}+$ Fertilizer $_{75 \mathrm{~N}}$ & 12.0 & 11.95 & 35.3 & 41.8 & 44.8 & 51.5 \\
\hline$T_{6}$ & VC $_{25 \mathrm{~N}}+$ Fertilizer $_{75 \mathrm{~N}}$ & 11.5 & 11.78 & 35.8 & 40.4 & 45.6 & 50.3 \\
\hline $\mathbf{T}_{7}$ & RDF & 11.4 & 11.74 & 35.8 & 40.8 & 45.5 & 50.8 \\
\hline \multicolumn{2}{|c|}{ SEm \pm} & 0.36 & 0.32 & 0.84 & 1.24 & 1.02 & 1.42 \\
\hline \multicolumn{2}{|c|}{$\mathrm{CD}(\mathrm{P}=0.05)$} & NS & NS & NS & NS & NS & NS \\
\hline \multicolumn{8}{|c|}{ In wheat } \\
\hline $\mathbf{F}_{1}$ & $50 \% \mathrm{RDF}$ & 10.2 & 10.29 & 31.8 & 37.7 & 40.1 & 46.3 \\
\hline $\mathbf{F}_{2}$ & $75 \% \mathrm{RDF}$ & 11.9 & 12.36 & 36.0 & 43.0 & 45.8 & 53.1 \\
\hline $\mathbf{F}_{3}$ & $100 \% \mathrm{RDF}$ & 13.4 & 13.61 & 40.5 & 46.4 & 52.0 & 57.5 \\
\hline \multicolumn{2}{|c|}{ SEm \pm} & 0.27 & 0.42 & 0.67 & 0.90 & 0.98 & 1.12 \\
\hline \multicolumn{2}{|c|}{$\mathrm{CD}(\mathrm{P}=0.05)$} & 0.78 & 1.22 & 1.94 & 2.6 & 2.83 & 3.24 \\
\hline
\end{tabular}

FYM= Farm yard manure, Forti=Fortified, 50N = 50\% Nitrogen, VC= Vermicompost, RDF= Recommended dose of fertilizer

Table.7 Treatment effects on protein content (\%) in wheat grain during, 2015-16 and 2016-17

\begin{tabular}{|c|c|c|c|}
\hline \multirow{2}{*}{\multicolumn{2}{|c|}{$\begin{array}{l}\text { Treatment } \\
\text { In maize }\end{array}$}} & \multicolumn{2}{|c|}{ Protein content $(\%)$} \\
\hline & & \multirow{2}{*}{$\begin{array}{c}2015-16 \\
9.38\end{array}$} & \multirow{2}{*}{$\begin{array}{c}2016-17 \\
8.94\end{array}$} \\
\hline $\mathbf{T}_{1}$ & FYM $_{50 \mathrm{~N}}+$ Fertilizer $_{50 \mathrm{~N}}$ & & \\
\hline $\mathbf{T}_{2}$ & Forti. VC $_{50 \mathrm{~N}}+$ Fertilizer $_{50 \mathrm{~N}}$ & 9.25 & 9.06 \\
\hline $\mathbf{T}_{3}$ & $\mathrm{VC}_{50 \mathrm{~N}}+$ Fertilizer $_{50 \mathrm{~N}}$ & 9.31 & 9.13 \\
\hline $\mathbf{T}_{4}$ & $\mathrm{FYM}_{25 \mathrm{~N}}+$ Fertilizer $_{75 \mathrm{~N}}$ & 9.44 & 9.00 \\
\hline $\mathbf{T}_{5}$ & Forti. $\mathrm{VC}_{25 \mathrm{~N}}+$ Fertilizer $_{75 \mathrm{~N}}$ & 9.38 & 9.06 \\
\hline $\mathbf{T}_{6}$ & $\mathrm{VC}_{25 \mathrm{~N}}+$ Fertilizer $_{75 \mathrm{~N}}$ & 9.31 & 9.00 \\
\hline $\mathbf{T}_{7}$ & RDF & 9.25 & 9.13 \\
\hline \multicolumn{2}{|c|}{ SEm \pm} & 0.14 & 0.11 \\
\hline \multicolumn{2}{|c|}{$\mathrm{CD}(\mathrm{P}=0.05)$} & NS & NS \\
\hline \multicolumn{4}{|c|}{ In wheat } \\
\hline $\mathbf{F}_{1}$ & $50 \% \mathrm{RDF}$ & 9.13 & 8.88 \\
\hline $\mathbf{F}_{2}$ & $75 \% \mathrm{RDF}$ & 9.38 & 9.06 \\
\hline $\mathbf{F}_{3}$ & $100 \% \mathrm{RDF}$ & 9.50 & 9.19 \\
\hline \multicolumn{2}{|c|}{ SEm \pm} & 0.24 & 0.15 \\
\hline \multicolumn{2}{|c|}{$\mathrm{CD}(\mathrm{P}=0.05)$} & NS & NS \\
\hline
\end{tabular}

FYM $=$ Farm yard manure, Forti $=$ Fortified, $50 \mathrm{~N}=50 \%$ Nitrogen, VC= Vermicompost, RDF= Recommended dose of fertilizer 
Table. 8 Treatment effects on grain yield $\left(\mathrm{kg} \mathrm{ha}^{-1}\right)$ and stover yield $\left(\mathrm{kg} \mathrm{ha}^{-1}\right)$ of maize crop during, 2015 and 2016

\begin{tabular}{|c|c|c|c|c|c|}
\hline \multirow{2}{*}{\multicolumn{2}{|c|}{$\begin{array}{l}\text { Treatment } \\
\text { In maize }\end{array}$}} & \multirow{3}{*}{$\begin{array}{c}\text { Grain yield } \\
2015 \\
3611\end{array}$} & \multirow{2}{*}{$\frac{\left(\mathbf{k g ~ h a}^{-\mathbf{1}}\right)}{2016}$} & \multicolumn{2}{|c|}{ Stover yield $\left(\mathrm{kg} \mathrm{ha}^{-1}\right)$} \\
\hline & & & & 2015 & 2016 \\
\hline $\mathbf{T}_{1}$ & $\mathrm{FYM}_{50 \mathrm{~N}}+$ Fertilizer $_{50 \mathrm{~N}}$ & & 3819 & 5416 & 5671 \\
\hline $\mathbf{T}_{2}$ & Forti. $\mathrm{VC}_{50 \mathrm{~N}}+$ Fertilizer $_{50 \mathrm{~N}}$ & 3859 & 4048 & 5789 & 6032 \\
\hline $\mathbf{T}_{\mathbf{3}}$ & $\mathrm{VC}_{50 \mathrm{~N}}+$ Fertilizer $_{50 \mathrm{~N}}$ & 3785 & 3849 & 5612 & 5819 \\
\hline $\mathbf{T}_{4}$ & $\mathrm{FYM}_{25 \mathrm{~N}}+$ Fertilizer $_{75 \mathrm{~N}}$ & 3877 & 4093 & 5770 & 5942 \\
\hline $\mathbf{T}_{5}$ & Forti. $\mathrm{VC}_{25 \mathrm{~N}}+$ Fertilizer $_{75 \mathrm{~N}}$ & 4287 & 4307 & 6224 & 6384 \\
\hline $\mathbf{T}_{6}$ & $\mathrm{VC}_{25 \mathrm{~N}}+$ Fertilizer $_{75 \mathrm{~N}}$ & 4122 & 4209 & 6066 & 6244 \\
\hline $\mathbf{T}_{7}$ & RDF & 4275 & 4413 & 6282 & 6523 \\
\hline \multicolumn{2}{|c|}{ SEm \pm} & 180 & 144 & 220 & 176 \\
\hline \multicolumn{2}{|c|}{$\mathrm{CD}(\mathrm{P}=0.05)$} & 554 & 444 & 677 & 542 \\
\hline \multicolumn{6}{|c|}{ In wheat } \\
\hline $\mathbf{F}_{1}$ & $50 \% \mathrm{RDF}$ & - & 4036 & - & 5993 \\
\hline $\mathbf{F}_{2}$ & $75 \% \mathrm{RDF}$ & - & 4124 & - & 6096 \\
\hline $\mathbf{F}_{3}$ & $100 \% \mathrm{RDF}$ & - & 4156 & - & 6174 \\
\hline \multicolumn{2}{|c|}{ SEm \pm} & - & 78 & - & 114 \\
\hline \multicolumn{2}{|c|}{$\mathrm{CD}(\mathrm{P}=0.05)$} & - & NS & - & NS \\
\hline
\end{tabular}

FYM= Farm yard manure, Forti= Fortified, 50N= 50\% Nitrogen, VC= Vermicompost, RDF= Recommended dose of fertilizer

Table.9 Treatment effects on grain yield $\left(\mathrm{kg} \mathrm{ha}^{-1}\right)$ and straw yield $\left(\mathrm{kg} \mathrm{ha}^{-1}\right)$ of wheat during, 2015-16 and 2016-17

\begin{tabular}{|c|c|c|c|c|c|}
\hline \multirow{2}{*}{\multicolumn{2}{|c|}{$\begin{array}{l}\text { Treatment } \\
\text { In maize }\end{array}$}} & \multicolumn{2}{|c|}{$\begin{array}{c}\text { Grain yield } \\
\left(\mathrm{kg} \mathrm{ha}^{-1}\right)\end{array}$} & \multicolumn{2}{|c|}{$\begin{array}{c}\text { Straw yield } \\
\left(\mathrm{kg} \mathrm{ha}^{-1}\right)\end{array}$} \\
\hline & & $2015-16$ & $2016-17$ & $2015-16$ & $2016-17$ \\
\hline $\mathbf{T}_{1}$ & $\mathrm{FYM}_{50 \mathrm{~N}}+$ Fertilizer $_{50 \mathrm{~N}}$ & 3640 & 3850 & 5135 & 5908 \\
\hline $\mathbf{T}_{2}$ & Forti. VC $_{50 \mathrm{~N}}+$ Fertilizer $_{50 \mathrm{~N}}$ & 3610 & 3786 & 5010 & 5848 \\
\hline $\mathbf{T}_{3}$ & $\mathrm{VC}_{50 \mathrm{~N}}+$ Fertilizer $_{50 \mathrm{~N}}$ & 3518 & 3744 & 5045 & 5808 \\
\hline $\mathbf{T}_{4}$ & $\mathrm{FYM}_{25 \mathrm{~N}}+$ Fertilizer $_{75 \mathrm{~N}}$ & 3584 & 3754 & 5020 & 5780 \\
\hline $\mathbf{T}_{5}$ & Forti. $\mathrm{VC}_{25 \mathrm{~N}}+$ Fertilizer $_{75 \mathrm{~N}}$ & 3532 & 3688 & 4970 & 5654 \\
\hline $\mathbf{T}_{6}$ & $\mathrm{VC}_{25 \mathrm{~N}}+$ Fertilizer $_{75 \mathrm{~N}}$ & 3494 & 3680 & 4975 & 5612 \\
\hline $\mathbf{T}_{7}$ & RDF & 3452 & 3646 & 4910 & 5590 \\
\hline \multicolumn{2}{|c|}{ SEm \pm} & 108 & 120 & 126 & 186 \\
\hline \multicolumn{2}{|c|}{$\mathrm{CD}(\mathbf{P}=0.05)$} & NS & NS & NS & NS \\
\hline \multicolumn{6}{|c|}{ In wheat } \\
\hline $\mathbf{F}_{1}$ & $50 \% \mathrm{RDF}$ & 3197 & 3340 & 4541 & 5235 \\
\hline $\mathbf{F}_{2}$ & $75 \% \mathrm{RDF}$ & 3501 & 3790 & 4935 & 5805 \\
\hline $\mathbf{F}_{3}$ & $100 \% \mathrm{RDF}$ & 3944 & 4076 & 5552 & 6189 \\
\hline \multicolumn{2}{|c|}{ SEm \pm} & 72 & 94 & 98 & 162 \\
\hline \multicolumn{2}{|c|}{$\mathrm{CD}(\mathrm{P}=0.05)$} & 208 & 272 & 283 & 469 \\
\hline
\end{tabular}

FYM= Farm yard manure, Forti=Fortified, 50N = 50\% Nitrogen, VC= Vermicompost, RDF= Recommended dose of fertilizer 
Fig.1 Treatment effects on biological yield of maize, (a) 2015 and (b) 2016
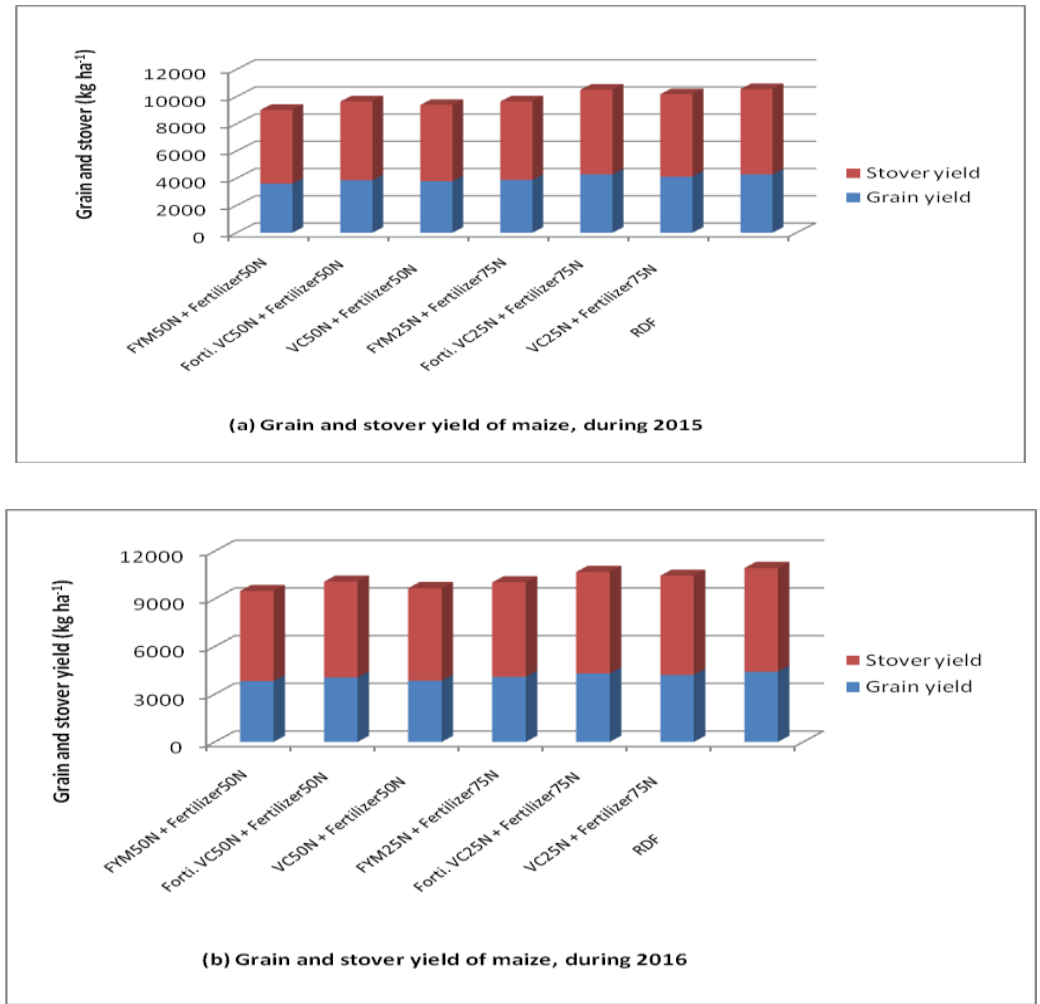

Fig.2 Treatment effects on biological yield of wheat, (a) 2015-16 and (b) 2016-17
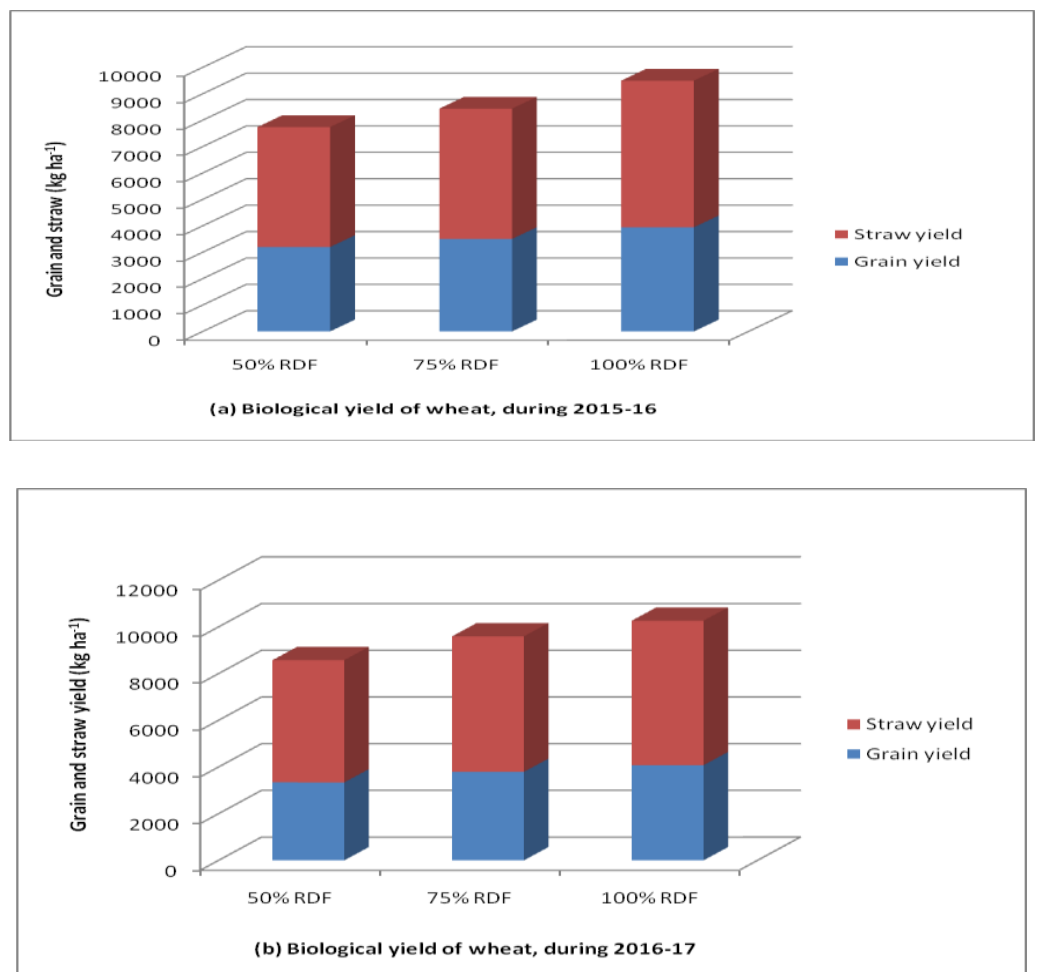


\section{Conclusion}

Nutrient management treatments in maize and fertilizer treatments to wheat have not influenced contents of NPK as well as protein content both in grain and stover of maize.

Higher uptake of NPK in grain, stover and total of maize was recorded with $25 \% \mathrm{~N}$ through fortified vermicompost $+75 \% \mathrm{~N}$ through fertilizer $\left(\mathrm{T}_{5}\right)$ remaining at par with $25 \% \mathrm{~N}$ through vermicompost $+75 \%$ $\mathrm{N}$ through fertilizer $\left(\mathrm{T}_{6}\right)$ and recommended dose of fertilizers $\left(\mathrm{T}_{7}\right)$

NPK content as well as protein content in grain and straw of wheat were not affected by the fertilizer levels applied to wheat during both the years. However NPK uptake by grain and straw of wheat was significantly higher in the $100 \%$ recommended dose of fertilizer compared to $75 \%$ and $50 \%$ recommended dose of fertilizer during both years.

Application of $25 \%$ of nitrogen either through fortified vermicompost or vermicompost along with $75 \%$ nitrogen through inorganic fertilizer was found to be as effective as $100 \%$ NPK through chemical fertilizers enhancing the growth and yield attributes of maize. Higher grain and stover yields of maize could be obtained even with substitution of $50 \%$ nitrogen either through fortified vermicompost or vermicompost except substitution on by farm yard manure.

The residual effect of combined application of organic and inorganic sources of nutrients as well as NPK through chemical fertilizers applied in maize was found to be non-significant in respect of growth, development and yield of succeeding wheat crop.

\section{References}

Anonymous. 2017. Agricultural statistical a glance 2016. Directorate of economics and statistics, Department of Agricultural and Cooperation, Ministry of Agriculture and Farmers Welfare, Government of India pp 1489

Arnon I. 1975. Mineral nutrition of maize. International Potash Research. Bern. Switzerland. pp 210-241

Black CA. 1965. Methods of soil analysis Part-I, American Society of Agronomy. Madison, Wisconsin, USA

Channabasanagowda NK, Patil BN, Awaknavar JS, Ninganur BT and Hunje R. 2008. Effect of organic manures on growth, seed yield and quality of wheat. Karnataka Journal of Agricultural Sciences 21 (3): 366368

Chaudhary JB and Singh CM. 1992. Study on production potential and economic evaluation of maize-based cropping system under mid hill conditions of Himachal Pradesh. Farming Systems 8 (3-4): 70-78

Choudhary and Kumar PS. 2013. Maize production, economics and soil productivity under different organic source of nutrients in eastern Himalayan region, India. International Journal of Plant Production 7 (2): 167-186

DeForest JL, Smemo KA, Burke DJ, Elliot HL and Becker JC. 2012. Soil microbial responses to elevated phosphorus and $\mathrm{pH}$ in acidic temperate deciduous forests. Biogeochem 109: 189-202

Dwivedi SK, Meshram MR and Pandey N. 2014. Response of customized fertilizer on wheat (Triticum aestivum) under Chhattisgarh conditions. The Bioscan 9 (4): 1509-1512 
Jackson ML.1973. Soil Chemical analysis. Prentice hall of India, Ltd. New Delhi pp 219-221

Kannan RL, Dhivya M, Abinaya D, Krishna RL and Kumar SK. 2013. Effect of integrated nutrient management on soil fertility and productivity in maize. Bulletin of Environment, Pharmacology and Life Sciences 2 (8): 61-67

Kumar A and Dhar S. 2010. Evaluation of organic and inorganic sources of nutrients in maize (Zea mays) and their residual effect on wheat (Triticum aestivum) under different fertility levels. Indian Journal of Agricultural Sciences 80 (5): 364-371

Kumar M. 2015. Effect of NPK levels and vermicompost on growth and yield of wheat (Triticum aestivum L.) under normal practice and system of wheat intensification. M Sc. Thesis, Department of Agronomy, Institute of Agricultural Sciences, BHU, Varanasi

Mahala HL, Shaktawat MS and Shivran RK. 2006. Direct and residual effects of sources and levels of phosphorus and farmyard manure in maize (Zea mays) mustard (Brassica juncea) cropping sequence. Indian Journal of Agronomy 51 (1): 10-13

Malghani AL, Malik AU, Sattarb A, Hussaina F, Abbasc G and Hussaind J. 2010. Response of growth and yield of wheat to NPK fertilizer. Science International 24 (2): 185-189

Manjhi RP, Yadava MS and Thakur R. 2014. Effect of integrated nutrient management on crop productivity and changes in soil fertility in maize (Zea mays)-wheat (Triticum aestivum) cropping sequence. Indian Journal of Agronomy 59 (3): 371-376

More S, Deshmukh S, Shinde $\mathrm{P}$ and Deshmukh V. 2013. Effect of integrated nitrogen management with vermiwash in corn (Zea mays L.) on growth and yield. African Journal of Agricultural Research 8 (38): 47614765

Nasab MV, Mobasser HR and Ganjali HR. 2015. Effect of different levels of vermicompost on yield and quality of maize varieties. Biological Forum An International Journal 7 (1): 856860

Piper CS. 1966. Soil and Water analysis. (Asian edition) Hans Publication, Bombay, India 223-237

Ravi N, Basavarajappa R, Chandrashekar CP, Harlapur SI, Hosamani MH and Manjunatha MV. 2012. Effect of integrated nutrient management on growth and yield of quality protein maize. Karnataka Journal of Agricultural Sciences 25 (3): 395-396

Saini JP and Kumar R. 2014. Long term effect of organic sources of nutrients on productivity and soil health in maize+soybean-wheat+gram cropping system. RAHMANN G \& AKSOY U (Eds.) (2014) Proceedings of the $4^{\text {th }}$ ISOFAR Scientific Conference. 'Building Organic Bridges', at the Organic World Congress, 13-15 Oct., Istanbul, Turkey

Samaneh R, Ali AH and Hosein MSHS. 2013. Effects types of vermiwash on wheat growth indices, yield and zinc, iron and phosphorus uptake in wheat grain. Iranian Journal of Soil and Water Research Journal 44 (2): 203-211

Shah JA, Depar N, Memon MY, Aslam M and Sial NA. 2013. Integration of organic and mineral nutrient sources enhances wheat production nuclear institute of Agriculture Tandojam. Pakistan Journal of Agriculture 29 (2): 106-113

Shah RA and Wani BA. 2017. Yield, nutrient uptake and soil fertility of maize (Zea mays $L$.) as influenced by varying 
nutrient management practices under temperate conditions of Kashmir valley, India. Plant Archives 17 (1): 75-78

Sheoran HS, Duhan BS, Grewal KS and Sheoran S. 2015. Grain yield and NPK uptake of wheat (Triticum aestivum L.) as influenced by nitrogen, vermicompost and herbicide (Clodinafop propargyl). African Journal of Agricultural Research 10 (42): 3952-3961
Siddiqui AN, Akhter MN, Hossain MA, Sultana M and Ahmed B. 2013. Effect of nitrogen levels on yield parameters of wheat. Bangladesh Research Publications Journal 8 (1): 01-06

Tababtabaei SA and Ranjbar GH. 2012. Effect of different levels of nitrogen and potassium on grain yield and protein of triticale. International Research Journal of Applied and Basic Sciences 3 (2): 390-393

\section{How to cite this article:}

Karan Verma and Bindra, A.D. 2019. Impact of Integrated Nutrient Management on Nutrient Content, Nutrient Uptake, Protein Content and Grain Yield in Maize (Zea mays L.)-Wheat (Triticum aestivum L.) Cropping System in an Acid Alfisol. Int.J.Curr.Microbiol.App.Sci. 8(06): 899-917. doi: https://doi.org/10.20546/ijcmas.2019.806.109 